\title{
Chapter 9 \\ Potential of Reducing GHG Emission from REDD+ Activities in Indonesia
}

\author{
Rizaldi Boer
}

\begin{abstract}
Loss of forest cover in large scale in tropical region will have impact on climate significantly. This will change air pressure distribution and shift the typical global circulation patterns and change rainfall distribution. Its contribution to the increase of greenhouse gas emission will also enhance global warming and may increase the frequency and intensity of extreme climate events. Deforestation in the three tropical regions, Amazon, Central Africa, and Southeast Asia, still continues. Without significant change in forest protection efforts, the loss of forests in these three regions by 2050 will reach about 29,98 , and $44 \%$, respectively.

Indonesia has the largest tropical forest in SEA; the contribution of emission from land use change and forest (LUCF) reached $60 \%$ of the total national emission, much higher than energy sector. During the period 1990-2013, the total loss of natural forest reached about 19.7 million hectares or about 0.822 million ha per year. Without significant change in forest protection program, within the period 2010-2050, Indonesia may lose 43.4 million ha of forest or equivalent to deforestation rate of 1.08 million ha per year. Potential of reducing emission from REDD+ activities is quite big. By increasing expenses of the government by $1 \%$ annually on top of the external investment for technology change, without necessity of direct forest protection (e.g., increasing agriculture productivity reduces pressure on forests), the deforestation rate could reduce to about 0.337 million ha per year.

The issuance of innovative financing and incentive policies for improving land and forest management may further increase the potential of reducing emission from REDD+ activities. Some of the policies include the use of debt-for-nature swap (DNS) scheme for accelerating the development of forest management units in open access area, incentive for permit holders for accelerating the development of timber plantation on degraded land, and increase community access to fund for green investment. The incentive system for the permit holders is for handling land tenurial issues or conflicts. The incentive could be in the form of reducing or exemption of administration/retribution fees for certain period of time depending on the level of conflicts. Policy allowing for transferring the funds to a financing system is relatively easy to be accessed by the community such as blending
\end{abstract}

\footnotetext{
R. Boer $(\bowtie)$

Centre for Climate Risk and Opportunity Management in Southeast Asia and Pacific, Bogor Agricultural University; CCROM SEAP-IPB, Bogor, Indonesia

e-mail: rizaldiboer@gmail.com
} 
financing, a financing system that synergizes all financial sources such as CSR funding; government funding such as state budget (APBN); and local government budget (APBD) funds, banking, and international funding. This system can help leverage private funding and supports regional development by supporting community activities in urban agriculture and agroforestry including building human resource capacity through assistance and training activities.

Keywords Extreme weather/climate events - Tropical forest $\bullet$ Greenhouse gas emissions - REDD+ activities - Financing policies - Incentive and disincentive policies

\section{Key Message to Policy Makers}

- Loss of large scale of tropical forest will bring more and intensify extreme weather/climate events.

- Loss of forest in Indonesia 1990-2013 accounts for most of deforestation in Southeast Asia with average loss of about 0.822 Mha per year.

- From the period 2010-2050, Indonesia potentially can reduce its deforestation rate more than half of the current rate to 0.337 Mha per year.

- The potential reduction of the deforestation may be achieved by facilitating changes in technologies without necessity of direct forest protection.

- Implementation of innovative financing policies and incentive/disincentive system may further reduce emission from REDD+ activities.

- The payment from REDD+ activities might offset the government additional expenses incurred in facilitating the changes.

\subsection{Introduction}

Forest plays a significant role in regulating our climate. Regional climates were sensitive to change of types and density of vegetation (Dickinson and HendersonSellers 1988; Shukla et al. 1990; Dale 1997; Avisar and Werth 2005). Loss of forest cover in large scale directly alters the reflectance of the earth's surface, induces local warming or cooling, and finally changes air pressure distribution. The changes in air pressure distribution shift the typical global circulation patterns and change rainfall distribution. At present, deforestation of tropical regions continues at high rate (Houghton et al. 2012). The major impact of tropical deforestation on precipitation may occur in and near the deforested regions themselves. However, a strong impact will be propagated by teleconnections along the equatorial regions and to mid-latitudes and even high latitudes even though not as strong as in the low latitude. Based on climate modeling analysis, deforestation of tropical regions (Amazon, Central Africa, and Southeast Asia) significantly affects precipitation at mid- and high latitudes through hydrometeorological teleconnections (Avisar and Werth 2005). Without 
significant change in forest protection efforts, the loss of forests in these three regions by 2050 will reach about 29, 98, and $44 \%$, respectively (Schmitz et al. 2014).

Deforestation will also contribute to the increase of GHG emission to the atmosphere. In the long term, the increasing GHG concentration in the atmosphere will cause an increase in global temperature and global climate. New finding from the 5th AR of IPCC indicated that agriculture, forest, and other land uses represent 20-24\% of global emission. Without mitigation efforts, the contribution of this sector may increase to $30 \%$ by 2030 . The three tropical regions, South America (TSAm), Southeast Asia (SEA), and tropical Africa (Af), are the main contributors to the global emission from land use change and forestry (Fig. 9.1). In the last 50 years, the rate of the emission from this sector tended to increase, except in South America (Houghton et al. 2012), and it is the largest and most variable single contributor to the emission from land use change (Le Quere et al. 2013). It is clear that deforestation in the short term will affect the regional climate and in the long term enhances global warming causing the increase in frequency and intensity of extreme weather and climate events.

Among Southeast Asian countries, Indonesia has the largest forest area. Rate of deforestation fluctuates from year to year; however, in general it tended to increase. GHG emission from land use change and forest (LUCF) has been found to be the major contributor to the total national emission. It accounted for about $60 \%$ of the total national emission, much higher than energy sector (MoE 2010). Efforts for reducing national emission have been prioritized on this sector (Bappenas 2010). Potential of reducing emission from REDD+ activities, i.e., reducing deforestation and forest degradation, maintaining role of forest conservation, implementing

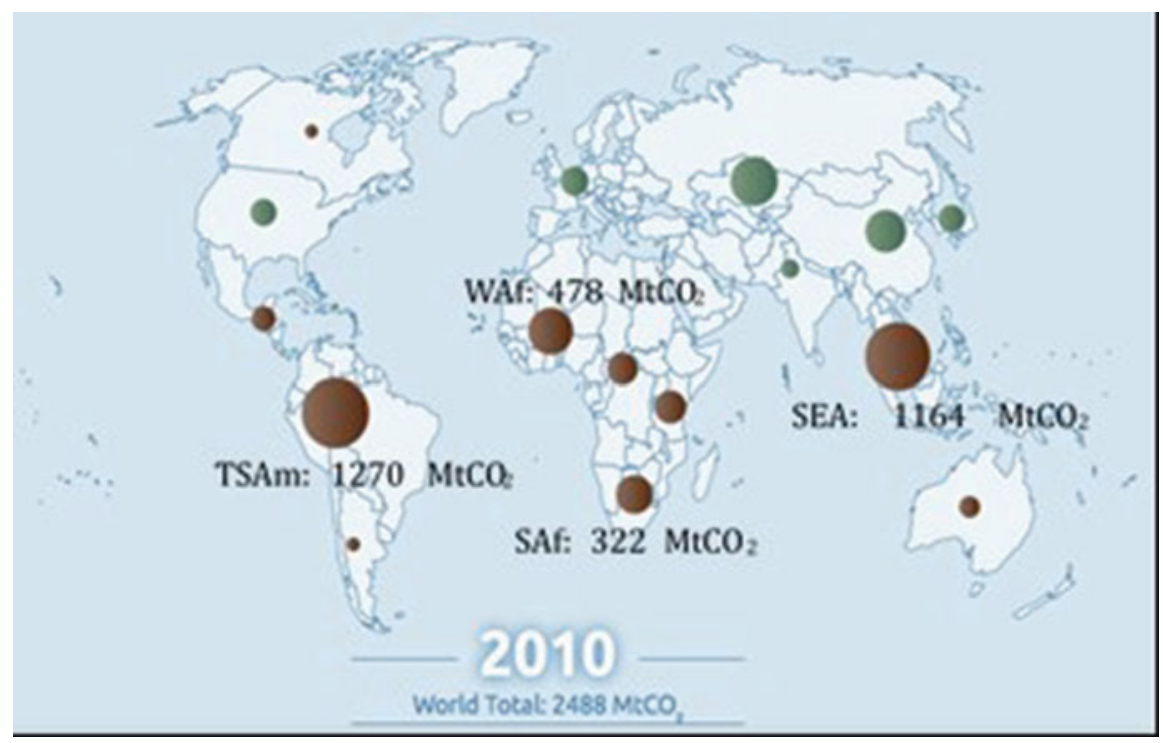

Fig. 9.1 CO2 emission from land use change and forest (http://www.globalcarbonatlas.org) 
sustainable forest management, and enhancing forest carbon sequestration, is quite big. Potentially the LUCF sector can become net sink by 2030 (MoE 2010). However, a number of innovative policies are required to realize this.

\subsection{Indonesian Forest}

In 2013, Indonesia has forest area of about 128.4 million ha and 59.4 million ha of non-forest area (APL; MoFor 2014). By function, the forest area is classified into 5 categories, namely, conservation forest (HK), protection forest (HL), limited production forest (HPT), production forest (HP), and convertible production forest (HPK). Conservation forest is designated for conservation purposes (Act No. 5/1990, Sanctuary Reserve area, Nature conservation, and Game Hunting Park), while protection forest to serve life support system, maintain hydrological system, prevent of flood, erosion control, and seawater intrusion, and maintain soil fertility. Production forest is aimed for timber and non-timber production, while convertible production forest (HPK) is for non-forest-based activities such as agriculture, settlement, etc. Thus, this forest can be released to become a non-forest area (APL).

Referring to its function, forest clearing and conversion of forest land in $\mathrm{HK}$ and HL to other land uses are not allowed. Deforestations occurred in these forests mostly from illegal activities such as logging, forest encroachments, and forest fires. On the contrary, forest clearings are permitted within HP and HPT, especially over unproductive forested areas for the purpose of establishing timber plantation. Unproductive forests comprised of forest areas with less than 25 core tress/ha with $\mathrm{dbh}$ of $20 \mathrm{~cm}$ up, less than 10 parent trees/ha, and insufficient/very few regeneration (numbers of seedling are less than 1000/ha, sapling less than 240/ha, and poles less than $75 / \mathrm{ha}$ ). It is thus obvious that not all degraded forests could be converted into plantation forests. HPK is legally designed for other uses, mainly for agriculture, transmigration, plantations, and settlements, thus all forest clearing activities.

Deforestation and forest degradation occurred in all types of forest functions either due to legal or illegal activities. Level of degradation of the secondary forest also varied from heavily to lightly degraded. With proper treatments, lightly to medium degraded forests can recover to reach climax forests. On the other hand, due to improper management and less strict law enforcement, degraded forests continue deteriorating resulting in severely degraded forests and meet unproductive forest criteria. In 2012, many of forest areas are not covered by forests, particularly in the production forest, and more than half of the remaining forests were secondary forests with various levels of degradation (Fig. 9.2).

High lost of forest cover in forest and implementation of unsustainable land management practices in non-forest area also caused serious damage on land. Forest functions as water retention, erosion control, nutrient cycling, microclimate regulator, and carbon retention were completely depleted. Many of the lands in both forest and non-forest areas are critical. Based on the level of damage, the critical 


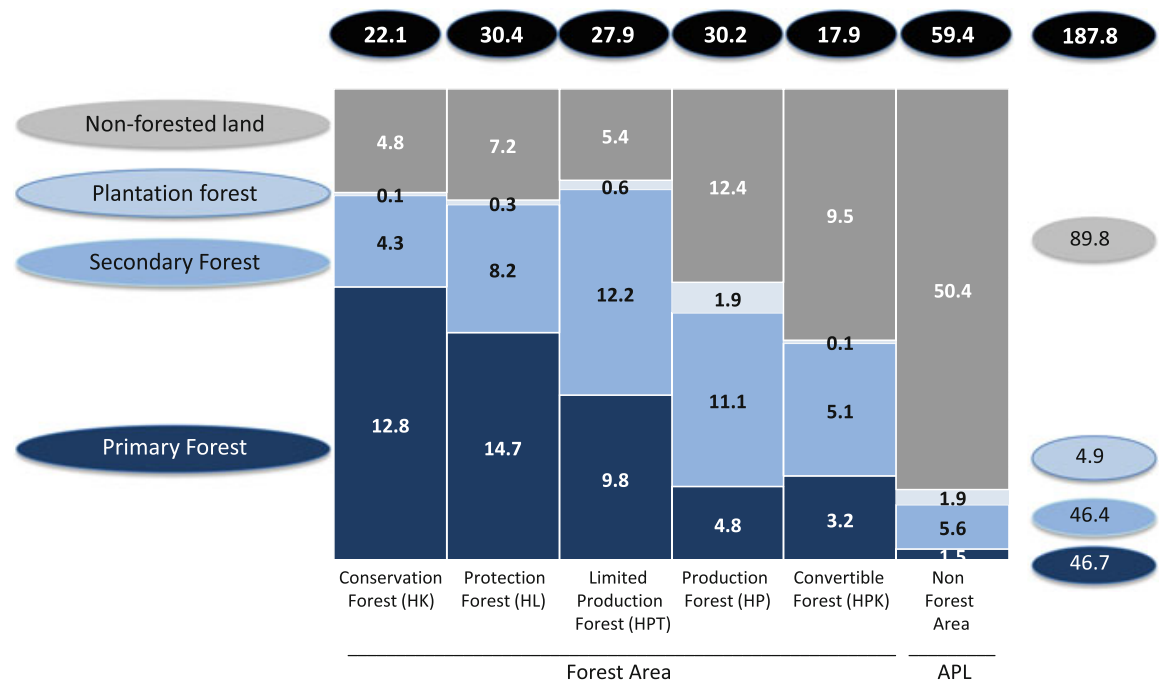

Fig. 9.2 Area and forest condition in 2013 (MoFor 2014)

lands are classified into five categories, i.e., very critical, critical, rather critical, potentially critical, and not critical. In 2011, the total area of critical lands had reached 27.3 million ha, comprised of 22.0 million ha critical and 5.3 million very critical (MoFor 2014). The critical and very critical lands have been prioritized for the implementation of land rehabilitation program.

\subsection{Deforestation and Trend of $\mathrm{CO2}$ Emission}

Factors causing deforestation and degradation varied among islands. In Sumatra in the early 1980s, the main driver of deforestation was the establishment of settlement through transmigration program, while in Kalimantan, it was mainly due to excessive timber harvesting (MoE 2003). Logging is not responsible for the deforestation of Indonesian forests. However, road network systems that have been developed during timber harvesting have opened the access of community to the forest area. Attractiveness of timber products, high agriculture income, and open access market have increased the insecurity of the forest. Combination of high logging extraction coupled with community encroachment has caused high rates of forest degradation and deforestation.

Based on recent data published by the Ministry of Environment and Forestry (MEF) during the period 1990-2013, the total loss of natural forest reached about 19.7 million hectares or about 0.822 million ha per year. The rate of the deforestation quite varied between periods (Fig. 9.3). The highest rate occurred during the period of 1996-2000 and the lowest in the period 2009-2012. The highest period 
Fig. 9.3 Rate of deforestation in Indonesia between 1990 and 2013 (Directorate of Forest Resource Inventory and Monitoring 2015)

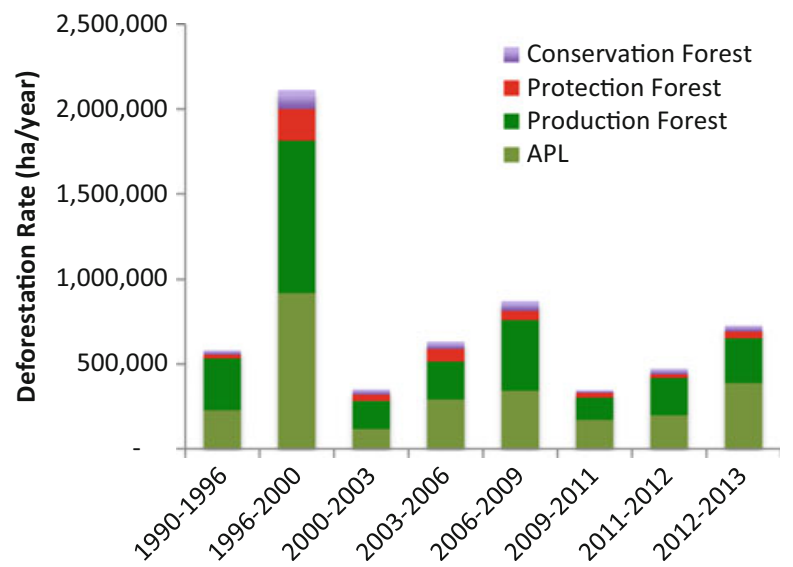

occurred during government transition period between new order ("orde baru") to reform ("reformasi") government.

Further analysis to land cover data of 1990-2013 showed that cropland conversion was found to be one of the key drivers causing deforestation (both commercial and subsistence agriculture). The loss of forest for the establishment of forest plantation, including expansion of settlement and other lands, is also quite significant even not as large as cropland (Fig. 9.4). Nevertheless, the area of grassland (including shrubs) also increased quite significantly during the period. This indicated that conversion of forest was not always used for meeting the land demand for development (for productive uses), but some were left as nonproductive lands. The data suggest that about half of the conversion of forest to non-forest lands ends up to grassland (including shrubs). In addition, the conversion of forest in the peatland for other uses tended to increase recently, particularly for the expansion of cropland, other lands, and establishment of timber plantation (Fig. 9.4). The rate of forest loss in the peatland is relatively higher than that in the mineral soils (Fig. 9.5).

The removal of biomass at the time of deforestation and forest degradation during the period of 1990-2013 was responsible for emission of about $0.693 \mathrm{Gt}$ $\mathrm{CO}_{2}$ per year. ${ }^{1}$ Emission from peat decomposition of the forest lands deforested and degraded since 1990 reached about $0.115 \mathrm{Gt} \mathrm{CO}_{2}$ per year (Fig. 9.6). Thus, in total the average emission due to deforestation and forest degradation occurred from 1990 to 2013 was $0.807 \mathrm{Gt} \mathrm{CO}_{2}$ /year. Busch et al. (2015) estimated that the average $\mathrm{CO}_{2}$ emission from deforestation and peat decomposition in the period of between 2000 and 2010 was about $0.859 \mathrm{Gt} \mathrm{CO}_{2}$ per year. Compared to this analysis, the rate of emission from deforestation and forest degradation during this period was about $0.884 \mathrm{Gt} \mathrm{CO}_{2}$ per year.

\footnotetext{
${ }^{1}$ Stock carbons of primary and secondary forest were about 156 and $126 \mathrm{tC} /$ ha respectively. The assumption was that all the removed biomass are emitted at the time of deforestation which is called as potential emission.
} 

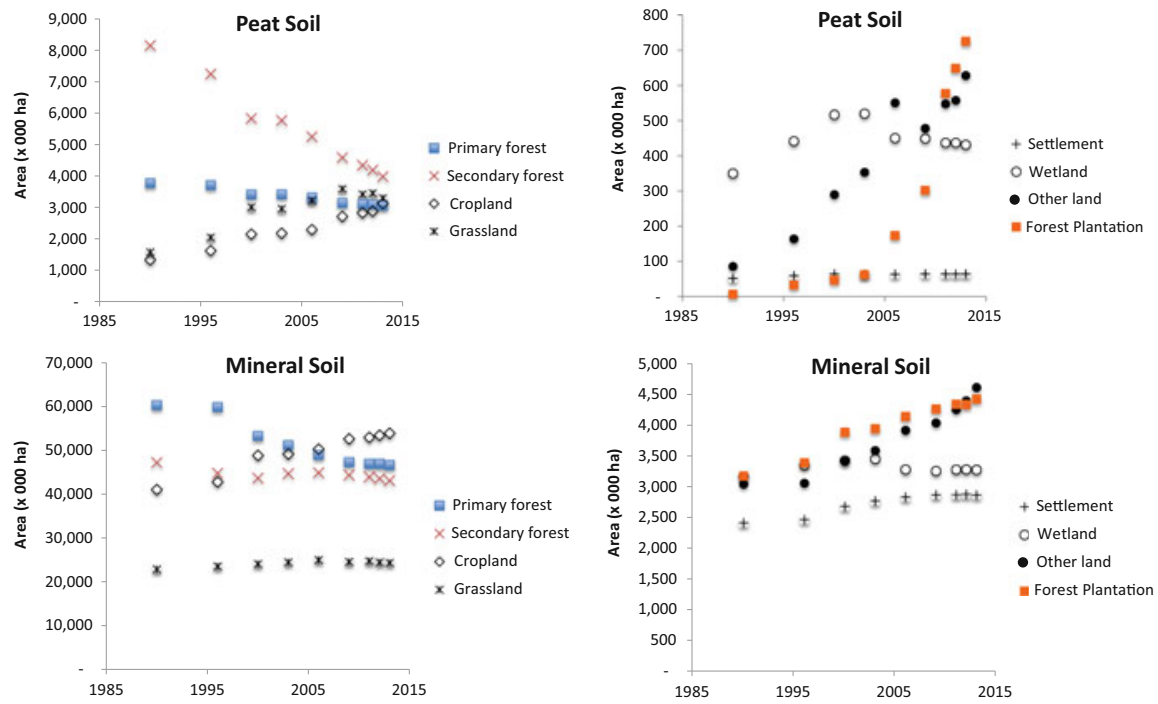

Fig. 9.4 Changes of forest land and non-forest lands in peat and mineral soils from 1990 to 2013 (Based on data from Directorate of Forest Resource Inventory and Monitoring 2015)

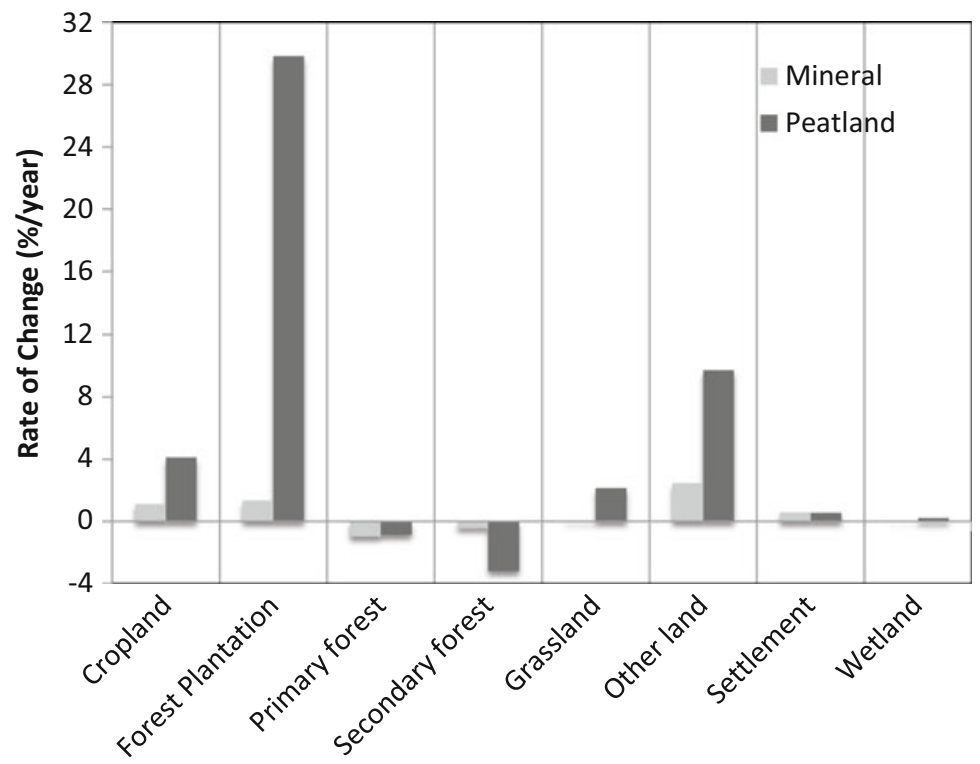

Fig. 9.5 Annual rate of change of forest lands and non-forest land areas in the period of 1990 to 2013 (Based on data from Directorate of Forest Resource Inventory and Monitoring 2015) 

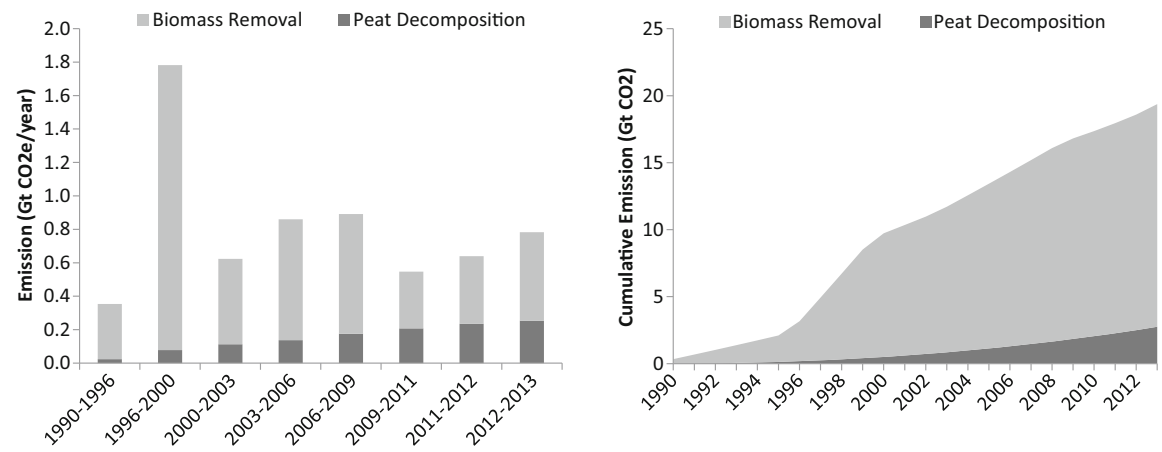

Fig. 9.6 Estimated gross $\mathrm{CO}_{2}$ emission from deforestation and forest degradation from 1990-2013 (Emission was from biomass removal at the time of deforestation and forest degradation (biomass loss from change of forest state from primary to secondary forest) and from peat decomposition (occurred from secondary forest, timber plantation, cropland and grassland and emission factor was taken from Hergoualc'h and Verchot, (2014). The carbon sequestration after the deforestation was not taken into account.)

\subsection{Low-Carbon Policies on Forest and Land Use Sector}

The Government of Indonesia has issued national policies and action plan for reducing emission from land use change and forestry defined in the Presidential Regulation Number 61/2011. In general there are four main policies and actions toward low carbon (Boer 2012). First is accelerating establishment of forest management unit (FMU) to improve the management of land and forest resources in all forest areas. Second is pushing adoption of sustainable management practices in production forests by implementing mandatory forest certification systems. Third is reducing dependency on natural forests in meeting wood demands through acceleration of establishment of timber plantation on community lands and state lands and enhancement of sink through restoration of production forests ecosystem and land rehabilitation. Fourth is reducing pressure on natural forest through optimization of the use of land and improvement of land productivity. To support the implementation of these policies and actions, it is crucial to develop financing/ incentive policies and development of financing system that can support their adoption and implementation by related stakeholders.

\subsubsection{Forest Management Units (FMUs)}

Key factors driving deforestation in Indonesia might originate from forestry sector and also from outside the forestry sector. These factors intermingle in complex processes, which are difficult to separate, which includes long drought period and characteristics of land that are rich in mineral resources but susceptible to fire 
interlink with management practices as well as political decision and economical considerations in the allocation of land uses, its utilizations and enforcement of rules. They both intend to pursue the goal of national development in forms of economical growth, political stability, as well as social equity and ecological sustainability. It is difficult to identify which key driver comes first and further stimulates the emergences of others. Some key drivers observed from current practices and have consequences on land use and land cover changes are forest fire, logging, timber plantation, agriculture expansion, mining, and political administration expansion.

Establishment of forest management unit (FMU) at site level has been considered as a prioritized program for improving management of forest resources and controlling deforestation and forest degradation. Urgency of FMU development especially outside $\mathrm{Java}^{2}$ is driven by the fact that (Nugroho et al. 2011):

1. Intensive management of forest resource at site level is required as mandated by Act No. 41 Year 1999 on Forestry which states that "All forests within the territory of the Republic of Indonesia, including natural resources contained therein is controlled by the State for the greatest prosperity of the people".

2. Management of forest resources given to the private sector through the licensing mechanism for forest (IUPHH) has limited time, and when it is over, the forest area becomes unmanaged. In addition, nature of the transfer of rights to holders of the license also required close monitoring from government over the behavior of the license holders.

3. Many of investments for land and forest rehabilitation implemented in forest area (GERHAN) often fail as due to the absence of manager in the site who will manage the maintenance of the planted trees.

4. Programs for giving access to public in playing active role in managing forest resources such as community-based plantation forest (HTR), village forest, and community forest $(\mathrm{HKm})$ are slowly realized, due to the absence of companion at the implementation level.

Duties and functions of the FMU (PP. 6/2007 jo PP. 3/2008) include (1) implementing management of forest resources which includes forest arrangement and management plan, utilization of forest area and resources, rehabilitation and reclamation of forest area, and protection and conservation of forest area; (2) translating national, provincial, and district/city forest policy to be implemented at site level; (3) implementing forest management activities in the region starting from planning, organizing, implementing, and monitoring and control; and (4) implementing the monitoring and the assessment of implementation forest management activities in its territory and opening investment opportunities to support the achievement of forest management objectives.

\footnotetext{
${ }^{2}$ FMU had already existed long before in all forest area in Java under the management of State Forest Company Perum Perhutani and called KPH (Kesatuan Pemangku Hutan).
} 
FMU is targeted to be developed 600 units throughout forest area, and by February 2014, only 120 units were established. However, operationalization of these first 120 units remains problematic (Nugroho et al. 2014). Some of the problems include:

1. Scope and authorities of FMU in managing forest area. FMU authority is actually very powerful, but this is supported by a number of different regulations, not summarized in one single regulation. So KPH management team is not functioning optimally. As an example, annual working plan of concession holder (RKT) should be approved via KPH once a respective area has established its KPH. Articles 71-78 of government law No. 6/2007 regulate this issue. However, none of RKT now is submitted to KPH. Its function on monitoring and evaluation of concessions does not work. Therefore, it is necessary to compile a list authority of KPH mandated by regulations and laws and issue a strategic regulation on this.

2. Capacity of stakeholders and supports from local government (Province/district) are still diverse. Dynamics of local politics also very much influence their commitments in running FMU.

3. Sectoral ego does exist. There is a doubt that some functions of forestry-related agencies will be taken over by FMU.

4. Regulation No. 23/2014 about local government authority on forestry issue (incl. KPHP and FMU for protection forest (KPHL)) results a concurrent between central government and provincial government (Article 14 (1)). The regulation also indicates less role of district government. However, sites are located within administrative authority of district government.

5. Many FMUs have been legalized by MoF decree, yet do not have any organization at site level (8 out of 120 units).

6. Barriers in regulating concessions incl. RHL and issue of coordination between FMU and concession holders.

7. Independence of FMU needs to be improved. A number of regulations such as No. 61/2007 about technical guidance of general service budget management (PPK - BLUD).

8. Lack of human resources and funding.

9. Need a synchronized policy and coordination among Echelon 1 at ministry of forestry to support operationalization of FMU.

10. Socialization of FMU development has been concentrated to forestry agency at provincial level. While communication on FMU policies by central government has not touched strategic decision making at local level.

11. Mechanism on national budget is not flexible for supporting FMU.

12. Land tenure conflicts as a consequence of non-FMU area rights. Local community often claims those areas. Ministry of forestry has very weak power on this type of areas.

13. Lack of leadership and entrepreneurship in FMU directors/heads.

As mentioned above (Problem No. 7), FMU independence is needed because often local government, i.e., majorly ask for benefits - specifically financial benefits 
Table 9.1 Budget management at BLUD and non-BLUD working units

\begin{tabular}{|c|c|c|c|}
\hline & Description & Non-BLUD & BLUD \\
\hline 1 & Administrator & Civil servant (PNS) & PNS and professional non-PNS \\
\hline 2 & Tariff of service & Based on fair/proper norms & Cost per service unit \\
\hline 3 & $\begin{array}{l}\text { Medium-term } \\
\text { document }\end{array}$ & $\begin{array}{l}\text { Medium-term development plan } \\
\text { (Rencana Pembangunan Jangka } \\
\text { Menengah-RPJM) }\end{array}$ & $\begin{array}{l}\text { Business strategic plan (Rencana } \\
\text { Strategis Bisnis, RSB) }\end{array}$ \\
\hline 4 & Budgeting & $\begin{array}{l}\text { Budget work plan (Rencana } \\
\text { Kerja Anggaran - RKA) }\end{array}$ & $\begin{array}{l}\text { Business budget plan (Rencana } \\
\text { Bisnis Anggaran }-R B A)\end{array}$ \\
\hline 5 & Budget allocation & $\begin{array}{l}\text { After DIPA (national budget) is } \\
\text { authorized }\end{array}$ & $\begin{array}{l}\text { Independent from national } \\
\text { budget }\end{array}$ \\
\hline 6 & $\begin{array}{l}\text { Financial } \\
\text { activities }\end{array}$ & $\begin{array}{l}\text { Petty cash and all other financial } \\
\text { activities are conducted via } \\
\text { PEMDA bank account }\end{array}$ & $\begin{array}{l}\text { Independent and has its own bank } \\
\text { account }\end{array}$ \\
\hline 7 & Income & Transferred to state account & Usable for operational \\
\hline 8 & Surplus & Transferred to state account & Usable for operational \\
\hline 9 & Debts & Not allowed & Allowed \\
\hline 10 & Financial reports & $\begin{array}{l}\text { Government accounting standard } \\
\text { (Standar Akuntansi Pemerintah- } \\
\text { SAP) }\end{array}$ & $\begin{array}{l}\text { Government accounting standard } \\
\text { (Standar Akuntansi Pemerintah- } \\
\text { SAP) and financial accounting } \\
\text { standard (Standar Akuntansi } \\
\text { Keuangan - SAK) }\end{array}$ \\
\hline 11 & Financial reports & Audit by BPK & Audit by independent auditor \\
\hline 12 & $\begin{array}{l}\text { Long-term } \\
\text { investment }\end{array}$ & Not allowed & Allowed \\
\hline 13 & Purchasing & Based on presidential regulation & Has its own regulation \\
\hline 14 & Cooperation & $\begin{array}{l}\text { Major/governor (local } \\
\text { government) }\end{array}$ & Head of working group \\
\hline
\end{tabular}

Source: Nugroho et al. (2014)

of KPH for their district. On the other side, running FMU needs independent financial support. State budget is limited, while to develop FMU as a full business entity will violate main objective of FMU. Proper format of FMU would be a quasigovernment body like BLUD. Central government should pay attention more on strategic regulation for this PPK BLUD then.

According to the ministry of domestic affairs regulation No. 61/2007, BLUD is SKPD or nonprofit working unit under local government, which is established to support and provide services for the respective areas. BLUD has flexibility in budget management compared to conventional working units (Table 9.1). Legal procedure for retribution mechanism of BLUD is also rather less complicated compared to conventional working units (Regulation No. 28/2009). Retribution mechanism usually should be supported by local regulation - approved by DPRD (local parliament) but for BLUD only need major or governor decree. 
In terms of giving more authority to FMU, based on inputs from local stakeholders, FMU which currently is only authorized to manage state forest area should also be given authority to manage non-forest area (CER Indonesia and CCAP 2010). By giving this authority, FMU can assist in managing REDD activities both within and outside forest areas. FMU should take the form of BLUD (Badan Layanan Umum Daerah - Local Service Unit). Having effective, strong, and independent FMU might be a key factor to the success of implementation of sustainable forest management.

\subsubsection{Forest Certification System}

Degradation of production forest is mainly triggered by the higher demand of wood for industry. Supply of timber from natural forests is not enough to meet the capacity of timber industry, and this leads to the increase of illegal logging activities. It is estimated that an additional supply of timber from illegal logging may be equal to that from the legal logging. The highest logging activities occurred in production forests $(60 \%)$ and then in the protected forest $(30 \%)$ and forest conservation $(10 \%)$. The level of illegal logging is estimated to be very high in the non-concession forest area of production forests (Tim Pokja Kementrian Kehutanan 2010). In other Asian countries, fuel wood collection and charcoal production for meeting domestic and local demand are also drivers of forest degradation (Hosonuma et al. 2012), even if their impact is not as much as that of illegal logging.

To reduce trading of illegal logs and to push application of sustainable forest management practices, the Government of Indonesia has established Timber Legality Assurance System (TLAS) through the issuance by the Minister of Forestry of Regulation Number P.38/Menhut-II/2009 on Standard for Evaluating Performance of Implementation of Sustainable Production Forest Management (PK-PHPL) and Verification of Legality of Logs (SVLK). This regulation is followed by the issuance by the Directorate General of Production Forest Regulation Number P.06/VI-Set/2009 and P2/VI-Set/2010. In TLAS, the assessment and verification of the timber products were done by independent third party, i.e., Entity for Evaluation of Performance and Independent Verifier (LP and VI) accredited by National Accreditation Committee (KAN). Other independent third parties such as Civil Society Organization and NGOs do the monitoring, i.e., for accommodating complaint from communities to the results of works from the LP and VI. With such process, TLAS will meet the good governance principles (transparency, accountability, and participatory), credibility (do not include government institution), and representativeness.

PK-PHPL is mandatory for all permit holders in state forests (IUPHHK-HA, IPPHHK-HT, IUPHHK-RE, HKm, and HTR) and private forests (Hutan Rakyat or 
HR), and SVLK is mandatory for all permit holders in state forests and private forests and also for all upstream and downstream wood industries (IUIPHHK). In principle, permit holders who already have certificate of PHPL will not require to have SVLK. Validity of the certificate is only for 3 years, and every year it is subject to surveillance. Up to January 2013, total forest areas that have been granted for IUPHHK-HA (logging concessions), IUPHHK-HT (Industrial Timber Plantation), and IUPHHK-RE (Restoration of Production Forest Ecosystem) were $20,899,673$ ha, 10.106 .540 ha, and 397,878 ha, respectively. community forest plantations (HTR and HKm) were 752,297 ha (MoFor 2014).

In addition to the mandatory certification, there are also some voluntary certifications of SFM using standard Lembaga Ecolabelling Indonesia (LEI), Forest Stewardship Council (FSC), and some others. However, the progress of the implementation of certification is quite slow. Since June 2011, the total number of companies who already have mandatory certification of SFM had only been 230 certificates covering a total area of about 19 million ha and for voluntary certification had only been 25 certificates (Table 9.2). A number of factors that need attention for accelerating the achievement of SFM are (Bahruni 2011):

1. Governance and regulations which promote forest good behavior and reduce inefficiency of bureaucracy, encourage professionalism in forest management, push high responsibility of forest management units in using their given rights and authorities, and implement improvement program in organization capacity and forest management skill including resolving land uncertainty issues (tenure and spatial layout)

2. Provision of incentive and disincentives for forest management units with good performance and bad performance (SFM and non-SFM units) and allowing non-SFM units to improve their performance by planning and conducting concrete actions within clear timeline to meet SFM

3. Development of carbon accounting system to evaluate the performance of forest management units in minimizing forest degradation

Table 9.2 Number of companies who already have certification of SFM

\begin{tabular}{|c|c|c|c|c|c|}
\hline \multirow[b]{2}{*}{ Category } & \multirow[b]{2}{*}{ Total concession area $(\mathrm{ha})^{1}$} & \multicolumn{2}{|c|}{$\begin{array}{l}\text { Mandatory certificates } \\
\text { (up to June 2011) }\end{array}$} & \multicolumn{2}{|c|}{$\begin{array}{l}\text { Voluntary } \\
\text { certificates (up to } \\
\text { June 2011) }\end{array}$} \\
\hline & & Number & Area (ha) & Number & Area (ha) \\
\hline IUPHHK-HA & $22,710,256$ & 140 & $14,225,443$ & 5 & 834,452 \\
\hline Very good-good & $n a$ & 31 & $3,449,955$ & na & $n a$ \\
\hline Average & $n a$ & 35 & $3,307,789$ & na & na \\
\hline Poor or expire & $n a$ & 74 & $7,467,699$ & $n a$ & $n a$ \\
\hline IUPHHK-HT & $9,963,770$ & 90 & $4,914,301$ & 3 & 544,705 \\
\hline Good & $n a$ & 19 & $2,499,280$ & na & na \\
\hline Expire & $n a$ & 71 & $2,415,021$ & na & na \\
\hline HR & $1,570,315$ & $\mathrm{Na}$ & na & 17 & 242,931 \\
\hline
\end{tabular}


To encourage the concession holders applying for the certification, the government needs to revisit the SFM performance indicators used by forest management units (FMUs) that have different nature of activities, i.e., between management of forest resources (IPHHK-HA) and management of forest ecosystem (IUPHHK-RE; Nugroho et al. 2011). Different from IPHHK-HA, holders of IUPHHK-RE will have no cash inflow for a number of years until forests are restored as the timber will be harvested after reaching the equilibrium of ecosystems (e.g., 35 years). Applying for the certification will increase the cost, while the IUPHHK-RE holders are burdened with the obligation to pay various fees as applied to IUPHHK-HA. It is understandable that none of IUPHHK-RE (restoration of ecosystem) holders apply for the mandatory certification. A number of studies have proven that applying SFM practices will ensure the sustainable wood production and reduce the degradation (see Box 9.1). The reduction of emission from forest degradation by applying SFM practices could reach $9.79 \mathrm{tCO}_{2} \mathrm{ha}^{-1}$ year $^{-1}$.

On the other hand, to conserve forests particularly forested land in forest area that have been released for non-forest-based activities, the Government of Indonesia also plans to apply mandatory certification system for palm oil called Indonesian Sustainable Palm Oil (ISPO). With this policy, all palm oil plantation companies will be obliged to conserve High Conservation Value (HCV) areas in their concession and to apply good practices in reducing GHG emissions. This policy is expected also to reduce deforestation. The ISPO will be officially effective as of March 2012, and it is targeted that all oil palm plantation companies will obtain the ISPO certificates by 2014. ISPO is launched to speed up the implementation of sustainable palm oil. ISPO is the same as existing sustainable standard RSPO (Roundtable on Sustainable Palm Oil); the only difference is that ISPO is compulsory, while RSPO is voluntary. Companies that have been certified by RSPO can receive ISPO certification after fulfilling some additional criteria. The regulation of ISPO is defined in the Ministry of Agriculture Regulation No. 19/Permentan/ OT.140/3/2011. ISPO is a response of the Government of Indonesia to meet increasing demand of market for sustainable and green products and participate in mitigating climate change.

The mandatory certification system may also be followed by other non-forestbased activities that may directly affect forest resources such as mining. It has been well known that Indonesian forests store mineral deposits underneath which are needed to develop the country. Rights to use the resources are granted by the government through the scheme of pinjam pakai or land leasing for certain period of time. Mining of the deposit starts by clear off not only woody biomass of the forest but also other biomasses stored underneath the soil. The activities produces high emission which will be difficult to restore them back as fertility of the soil will be gone. In many cases, most of forest areas left by the mining after the termination of its permit are under heavily degraded condition. 
To ensure the implementation of sustainable management principles and community economic development in exploiting natural resources (including mining), it may be necessary to introduce policy for limiting GHG emission (emission cap) from certain forest industries/concessionaires. The cap could be determined based on the result of the environmental impact assessment (EIA). Under current regulation, all forest industries/concessionaires obliged to conduct EIA. With the introduction of this policy, each entity must include the assessment of GHG emission level from their activities given all mandatory environmental management activities are met. Once the level of GHG emission is defined and estimated, this level of emission will be treated as "emission cap" of these entities. Theoretically entities that implement their environmental management plan defined in the EIA, the level of emission, should be low. Thus, companies that release more than the allowable emissions (emission cap) shall offset the excess.

\section{Box 9.1 Impact of Sustainable Forest Management (SFM) Practices on Carbon Stock Change at Logging Concession Companies (Source: Bahruni 2011)}

Based on data collected by Bahruni (2011) from five concessions (three concessions with SFM certification and two with non-SFM certification), it is quite clear that implementation of SFM practices can reduce emission from forest degradation. In non-SFM concessions, the volume of wood extracted relative to the annual allowable cut decreased significantly from year to year indicating continuous degradation of the forest, while in SFM concession, it is relatively constant (Fig. 9.7). Rate of forest degradation in SFM concessions was found to be between $0.17 \%$ and $0.37 \%$ per year and non-SFM between $2.35 \%$ and $2.61 \%$ per year and this equivalent to $\mathrm{CO}_{2}$ emission reduction of $9.76 \mathrm{tCO}_{2} \mathrm{ha}^{-1}$ year $^{-1}$ (Table 9.3).
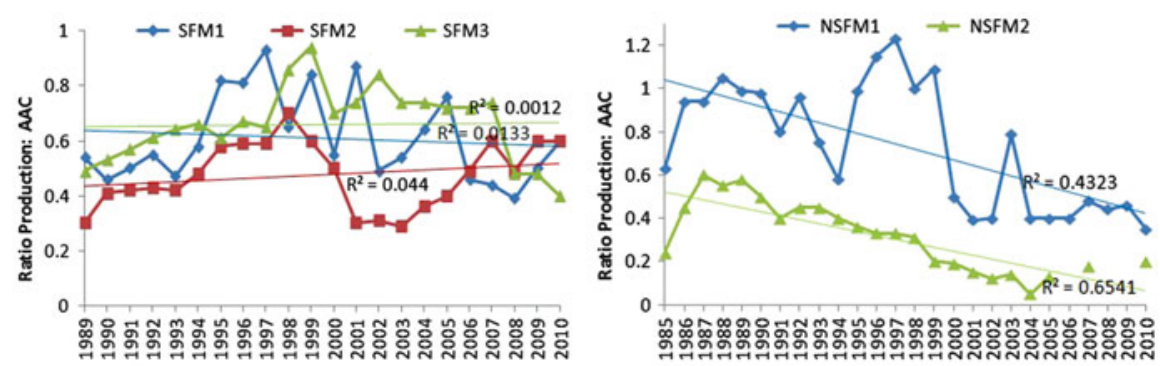

Fig. 9.7 Ratio between volume of wood extraction and annual allowable cut in SFN and non-SFM concessions 
Table 9.3 Estimated $\mathrm{CO} 2$ emission reduction from forest degradation

\begin{tabular}{l|l|l|l}
\hline \multirow{2}{*}{ Time period } & \multicolumn{3}{l}{ The rate of degradation $(\%)$} \\
\cline { 2 - 4 } & SFM & Non-SFM & Difference SFM and non-SFM \\
\hline $1992-2011$ & 0.37 & 2.35 & 1.98 \\
\hline $2000-2011$ & 0.17 & 2.61 & 2.44 \\
\hline The benefit of SFM & $1992-2011$ & $2000-2011$ \\
\hline \multicolumn{2}{l}{ The reduction of loss stand $\left(\mathrm{m}^{3} \mathrm{ha}^{-1}\right.$ year $\left.^{-1}\right)$} & 1.85 & 2.28 \\
\hline The reduction of emission $\left(\mathrm{tC} \mathrm{ha}^{-1}\right.$ year $\left.^{-1}\right)$ & 2.16 & 2.66 \\
\hline The reduction of emission $\left(\mathrm{tCO}_{2} \mathrm{ha}^{-1}\right.$ year $\left.^{-1}\right)$ & 7.93 & 9.76 \\
\hline
\end{tabular}

\subsubsection{Reduction of Dependency on Natural Forests for Wood Supply and Sink Enhancement}

In meeting wood demand, Indonesia already has begun to issue Timber Forest Product Utilization License (TPFUL) since the early 1970s, called as forest management right particularly for timber (forest concession or HPH). The highest number of concessions was in 1980 which is more than 500 units of concession with an area of 60 million hectares. After the enactment of Law No. 41 of 1999, forest concessions (HPH) were renamed as IUPHHK. Until now, the number of holders of IUPHHK for natural forests (HA) is declining to only about 256 units IUPHHK-HA. On the contrary IUPHHK for timber plantation (HT) increased from only a dozen units to 215 units by 2011, and community timber plantation (HTR) is also emerging with newly established plantation of about 0.63 million hectares involving more of 63000 heads of households $(\mathrm{HH})$.

HTI management unit is currently growing rapidly with total area more than 9.4 million hectares and targeted to grow to about 15.9 million hectares by 2030 (RKTN; Kemenhut 2011). Nevertheless community forest management (CFM) does not show significant development even though the Ministry of Forestry has set up high target (Table 9.4). So far IUPHHK-HTR that has been issued was only less than 100,000 hectares. Similarly both HKm and village forest also do not show significant improvement (Table 9.4). The schemes of HKm and HTR aim to revitalize the traditional wood-processing sector such as plywood and sawn-timber, in addition to increase the supply of raw materials for round-wood and paper and pulpwood industries. The program will enrich stock of carbon inside forest area by plantation activities done by smallholder farmers. It is expected by 2016 the plantations will meet its target to rehabilitate and improve productivity of degraded 5.4 million hectares of forest lands. Enrichment of forest carbon stock could be strengthened by investing the expansion of agroforestry system into the HKM and HTR schemes. On the other hand, private forest (Hutan Rakyat or HR) increased significantly only in Java, which is now reaching approximately 2.8 million hectares with production of about 6 million $\mathrm{m}^{3}$ timbers per year. HR will continue to expand along with the proliferation of timber processing industry.

For increasing carbon sequestration, the Government of Indonesia has also implemented a number of programs for rehabilitating the degraded forest and 
Table 9.4 Target, allocation, verification, and license issuance of community-based forestry up to 2010

\begin{tabular}{l|l|l|l|l|l}
\hline $\begin{array}{l}\text { Community- } \\
\text { based } \\
\text { forestry } \\
\text { program }\end{array}$ & $\begin{array}{l}\text { Target up } \\
\text { to } 2014 \\
\text { (Ha) }\end{array}$ & $\begin{array}{l}\text { Allocation } \\
\text { (Ha) }\end{array}$ & $\begin{array}{l}\text { Verification } \\
\text { (Ha) }\end{array}$ & $\begin{array}{l}\text { License issuance } \\
\text { by the Ministry } \\
\text { of Forestry (Ha) }\end{array}$ & $\begin{array}{l}\text { License issuance } \\
\text { by the governor/ } \\
\text { head of district } \\
\text { (Ha) }\end{array}$ \\
\hline $\begin{array}{l}\text { Community } \\
\text { forestry } \\
\text { (HKm) }\end{array}$ & 2.000 .000 & 400.000 & 203.573 & 80.181 & $30.485,55$ \\
\hline $\begin{array}{l}\text { Community } \\
\text { forest plan- } \\
\text { tation } \\
\text { (HTR) }\end{array}$ & 5.400 .000 & 631.628 & & & $90.414,89$ \\
\hline $\begin{array}{l}\text { Forest vil- } \\
\text { lage (HD) }\end{array}$ & 500.000 & 179.187 & 144.730 & 13.351 & $10.310,00$ \\
\hline Total & 7.900 .000 & 1.210 .815 & & 93.532 & $120.910,44$ \\
\hline
\end{tabular}

Source: Sub-Direktorat HKm, HD dan HTR Kemenhut (in Nugroho et al. 2011)

Table 9.5 Condition of production forest

\begin{tabular}{l|l|c}
\hline Category & Production forest condition & $\begin{array}{l}\text { Area } \\
\text { (million ha) }\end{array}$ \\
\hline 1 & $\begin{array}{l}\text { Production forests with medium to very low level of degradation and } \\
\text { now are still under management of concessionaires (IUPHHK-HA) }\end{array}$ & 6.75 \\
\hline 2 & $\begin{array}{l}\text { Production forests with medium level of degradation } \\
\text { (no concessionaires operate in the area) }\end{array}$ & 6.40 \\
\hline 3 & $\begin{array}{l}\text { Production forest with medium to very high level of degradation } \\
\text { (no concessionaires operate in the area) }\end{array}$ & 14.15 \\
\hline 4 & $\begin{array}{l}\text { Production forest with very high level of degradation (not meet forest } \\
\text { definition anymore) }\end{array}$ & 27.33 \\
\hline Total & \multicolumn{2}{|l}{5} \\
\hline
\end{tabular}

Source: Based on MoFor (2014) and Bahruni (2011)

lands. At present due to the unsustainable practices of forest management, about 55.62 million hectares of production forest have been degraded (MoFor 2014). The level of degradation can be seen in Table 9.5. Production forests under categories 2 and 3 are allocated for restoration of production forest ecosystem. Up to 2013, total area of degraded production forests that have been granted with IUPPHK-RE was only 397,878 ha. To increase the interest of private sector to invest in the restoration of production forest ecosystem (IUPHHK-RE), the government may need to revisit its policy and regulations as RE activity has different nature of activities with IPHHK-HA. An incentive system should also be introduced.

As previously mentioned, the holders of IUPHHK-RE may not have cash inflow for a number of years until forests are restored as the timber will be harvested after reaching the equilibrium of ecosystems (e.g., 35 years). On the other hand, before the business permit is issued, they are burdened with the obligation to pay many fees as applied to IUPHHK-HA. In most cases, the holders of IUPHHK-RE can 
survive as they received grants from foreign donors who request for preservation of the forest ecosystem. Nugroho et al. (2011) recommended restructuring the regulations on forest ecosystem restoration by involving the managers of ecosystem restoration, government, and society. First is that ecosystem restoration business is not profit-oriented business so that the treatments should be different from IUPHHK-HA. Second, the current regulations PP. 3/2007 jo PP. No.03/2008 and ministry regulations should be revised to incorporate fundamental substantial changes, particularly on rights and obligations of license holders. Third is introducing incentive system for holders of IUPHHK-RE as they actually carry out government obligation in restoring, conserving, and preserving forests that nearly have no beneficial products.

Policy to prioritize the use of degraded forest for establishment of timber plantation will enhance sink as carbon stock of timber plantation is much higher than the degraded land and forest. In addition, the government for many years has also implemented a program for rehabilitating lands in forest area (program reforestasi) and non-forest area (program penghijauan). In the last 10 years, the Government of Indonesia has accelerated this program through GERHAN (Gerakan Rehabilitasi Lahan dan Hutan). In the period of between 2003 and 2008 , total areas planted through GERHAN reached 1,767,559 ha or equivalent to about 300 thousand hectares per year or almost double than those implemented before this period. In the National Forestry Plan (RKTN; Kemenhut 2011), it is estimated that total degraded land in forest area that needs to be rehabilitated until 2030 is about 11.6 million ha. Therefore, rehabilitation of degraded land will be accelerated. Annually, it is targeted that at least 580 thousand hectares of degraded land is planted for rehabilitation.

Based on past experience in the implementation of the land rehabilitation program, it was found that the level of success of this program is still low due to lack of maintenance system (see Box 9.2) and no responsible management unit exists to maintain the planted trees. Without changing strategy in the implementation of GERHAN, the target being defined in the RKTN will not be achieved. For future program, the targeted area for GERHAN should be implemented in area where the FMU already exists, and whenever possible, its implementation should be integrated with CBFM program.

\subsubsection{Reduction of Pressure on Natural Forest by Optimizing Land Use and Improving Land Productivity and Community Livelihood}

In many regions, conversion of forest is mainly for agriculture activities either by community or by company. Community normally encroached to forest area illegally for planting annual crops or plantation, while company converted the forest to agriculture plantation after having permit. The encroachment occurred in all forest 
function but mainly in production forests. Therefore, many of forest areas are not covered by forest. On the other hand, the Ministry of Forestry releases conversion forest to local government to be used for non-forest-based activities where part of the area is still covered by forest, while the other part is already deforested and used by community. This condition often creates conflict between the community and company when local government issued permit to a company to use the land for plantation. Local government normally leaves the problem to company to solve, and this creates high social cost for the company. When this problem is not properly handled by companies, community will find new land and do encroachment again. In other case, communities expand their agriculture land through encroachment when their demand for land increases as the number of family increases. Looking at this condition, pressure on natural forest will continue if integrated efforts across related ministries and local governments are not in place.

\section{Box 9.2 Survival Rate of Trees Under GERHAN Program}

Based on assessment conducted by an independent consultant, PT Equality Indonesia on GERHAN Program implemented in 2006/2007 at West Java Province, it was found that the planted trees that can survive and form forest stand were only $20 \%$ even the total area planted over $80 \%$ of the target. On average based on evaluation in 13 districts in West Java Province, realization of GERHAN program reached $84 \%$, but the ones that survive were only about $53 \%$ (note: based on regulation from the Ministry of Forestry, the GERHAN program is considered to be successful if the survival rate over $56 \%$, without considering the condition of the trees). Further evaluation indicated that of the $53 \%$, the survived trees with healthy condition were only $42 \%$ (Fig. 9.8). Based on this condition, number of trees that can survive until forest stand on average will be about $18 \%(0.84 * 0.53 * 0.42)$.

(continued)

Fig. 9.8 Percentage of realization of planting area, survive trees, and healthy trees (Analyzed from data of PT. Equality Indonesia 2007)

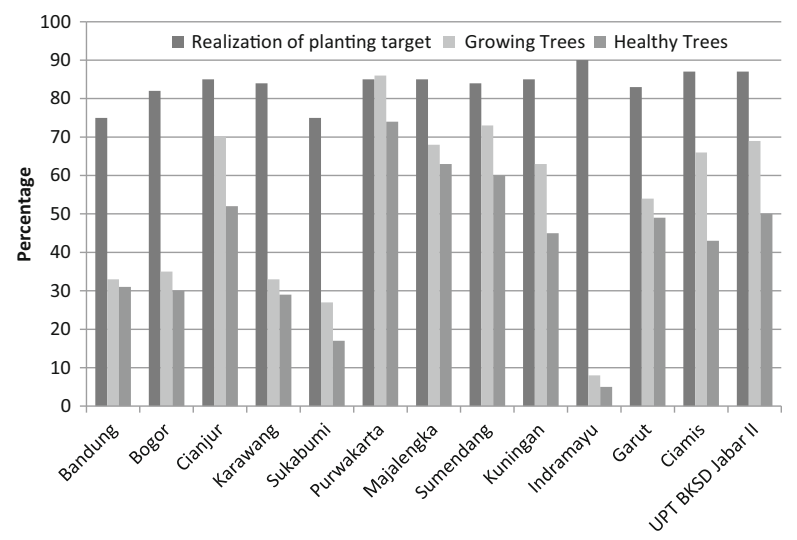


Box 9.2 (continued)

Based on observation, implementation of GERHAN program in Java islands was relatively better than those outside Java. Considering these findings, it can be estimated that the level of success of GERHAN program may be around $20 \%$. If there is no change in the implementation system of the GERHAN program, with average planting rate of about 300 thousand hectares per year, GERHAN areas which are able to form forest stand will be only 60 thousand hectare.

Policies and potential programs that have been discussed and proposed by stakeholders in reducing threat on natural forests and deforestation include the following:

1. Enforcement of plantation companies to engage community in their plantation as plasma farmers. Regulation on this is already available, i.e., Ministry of Agriculture Regulation No. 26/Permentan/OT.140/2/2007 about Guidance on Permit for Agriculture Plantation. In this regulation every plantation company is obliged to establish plasma plantation at least $20 \%$ of the total plantation area. However, many companies have not met this obligation. Following the implementation of mandatory certification system for plantations such as ISPO for palm oil, all companies are very likely to meet their obligation. In the case, where a company has already used all its land for plantation, the company will need to find land outside their plantation. If agriculture plantation commodities are allowed to be planted in forest area, this can be nicely integrated with community-based forest management (CBFM) program such as community timber plantation (HTR), community forest $(\mathrm{HKm})$, and hutan desa (village forest). At present, one of agriculture plantation commodity allowed to be planted in forest area is rubber tree, while palm oil is still not allowed. In South Sumatra, HTR program has been implemented in reforesting production forest area using rubber tree.

2. Improvement of crop productivity of small holder farmers. Most of communities that occupy forest area for agriculture activities are poor farmers and have little knowledge in good agriculture practices. For example, based on discussion with farmers who occupy Kerinci Seblat National Park (KSNP) in South Sumatra, it was stated that community tended to expand their agriculture lands to meet food demand and income of their family as their family is growing. By increasing crop productivity, the demand for land is expected to decrease (see Box 9.3). Creation of other alternative income for this community as well as their institutional capacity can increase the effectiveness of this program in reducing pressure on the forest. Development of synergy or integration of community empowerment programs from various sector and private (CSR) would be needed to enhance the effectiveness of this program.

3. Optimization of the use of non-forested land for agriculture activities by changing forest function. As shown in Figs. 9.1 and 9.2, more than 10 Mha of land in conversion forest is forested land, while about 20 Mha land in production forests is 


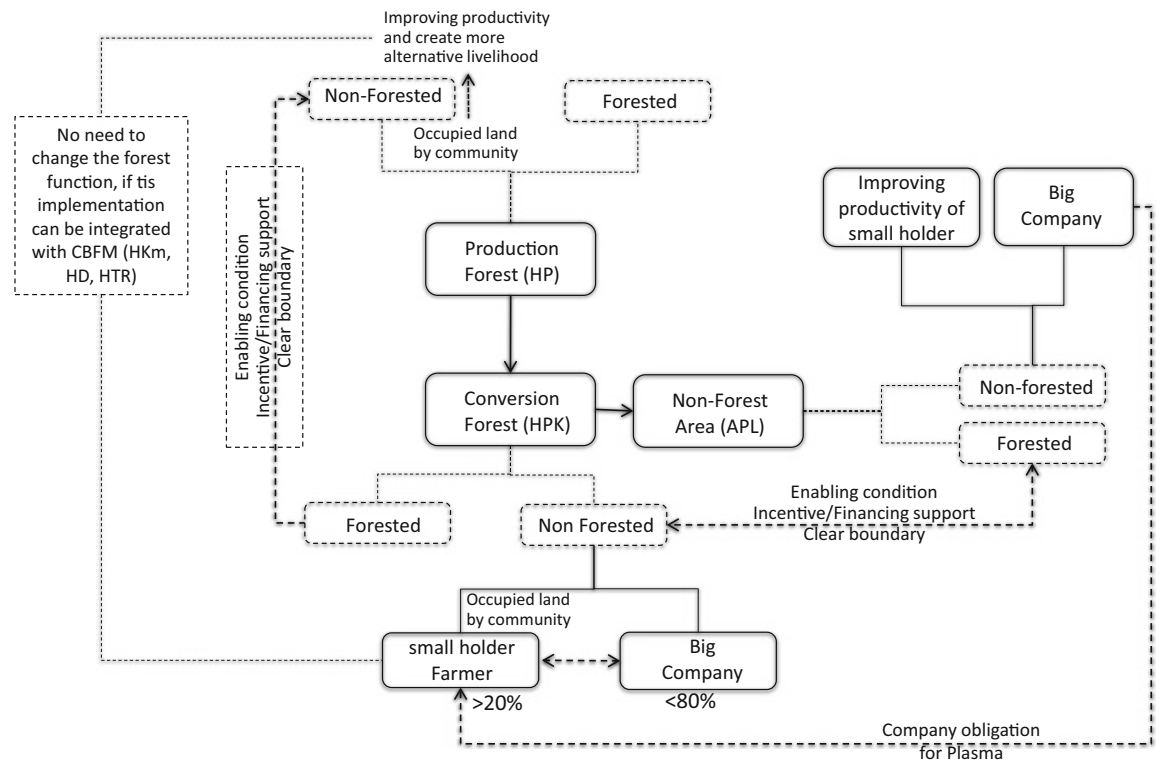

Fig. 9.9 Process for implementation of policy and program for reducing threat on natural forest and rate of deforestation (Modified from Boer et al. 2012)

non-forested land. In non-forest area, almost 7 Mha is forested land. Changing functions of forested conversion forest to production forest, and non-forested production forest to conversion forest which later can be released for non-forestbased activities (mainly for agriculture plantation) or swapping forested land in APL with non-forested conversion forest, would reduce future deforestation. Based on discussion with the staff of Planning Agency at Central Kalimantan Province, swapping forested land in non-forest area with non-forested production forest will be very difficult. It is suggested that before this land swap policy is applied, the status of non-forested production should be changed first to conversion forest. The Joint Minister Decree may be needed to implement this policy (Ministry of Forestry, Ministry of Internal Affairs, and National Land Agency). New direction on the utilization of forest area has been issued by the Ministry of Forestry in the RKTN (National Forestry Plan for 2011-2030), and this may need to be revisited if the policy is to be implemented. This land swap policy will also be potential to be integrated with mandatory certification and CFM programs. Obligation for agriculture plantation companies to develop plasma plantation with community with minimum area of about $20 \%$ of the total plantation may need additional lands. If agriculture plantation commodities are allowed to be planted in forest area, there is no need to change the status of forest function, and this program can be integrated with the CFM programs. Collaboration between the Ministry of Forestry and Ministry of Agriculture is required to facilitate this program.

Figure 9.9 summarized the process of implementing policy and programs for reducing threat on natural forest and deforestation. 


\subsection{Financing and Incentive Policies for Supporting the Implementation of SFM and REDD+}

To support the implementation of the above four key policies and actions, there are a number of financing and incentive policies that may need to be considered. These include (1) financing policies for the acceleration of FMU establishment, (2) incentive policies for the certification system, (3) financing and incentive policy for accelerating the establishment of timber plantation on degraded land and CFM for sink enhancement, and (4) incentive and financing policies for conserving forest carbon and land swap.

\subsubsection{Financial Policy for Development of FMUs}

As discussed above, the total number of FMUs that need to be established in Indonesia is about 600 units. Following target defined in the National Action Plan for reducing GHG emission (Appendix President Regulation 61/2011) within 5 years (2010-2014), the total number of FMUs that will be established is 120 units. With the total number of 600 FMUs, the time required to complete the establishment of FMU all over Indonesia would be 25 years. It is long process, with assumption that rate of deforestation in the future under the absence of FMUs follows historical rate; within the next 25 years, about 25 Mha of forest may be lost. Following Bappenas' assumption that the cost for establishing an FMU with selffunded capacity is 40 billion IDR ( 5 years), total cost required for the 600 units will be about 24 trillion IDR or 2.7 billion USD. Considering that this program will be a key for the success of REDD+, acceleration of FMUs establishment is necessary. Clear Roadmap on the Establishment of the all FMUs should be developed with secure budget. The Government of Indonesia may negotiate with donor countries to use debt-for-nature swap (DNS) scheme to secure budget to support the establishment of the FMU.

Box 9.3 Reducing Pressure on Kerinci Seblat National Park (Source: CER Indonesia and CCAP 2011)

Kerinci Seblat National Park (KSNP) is a part of the Bukit Barisan Mountain Range, stretching north to south along Sumatra Island. The park's location makes KSNP one of the richest conservation areas in terms of biodiversity. However, KSNP is under great threat of deforestation and forest degradation. A number of square kilometers of forest have been lost annually in the national park, severely reducing the natural environment for animals and other forest-dwelling life. The main drivers of deforestation and forest 
a

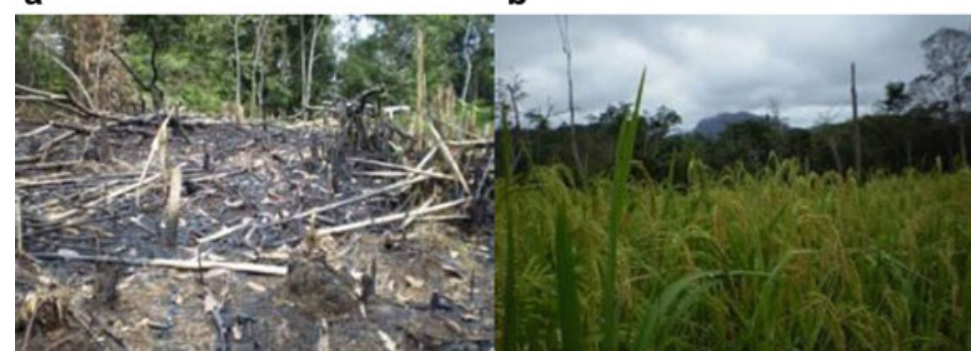

Fig. 9.10 (a) Slash and burn activity in KSNP, (b): agricultural land inside KSNP

\section{Box 9.3 (continued)}

degradation in KSNP are encroachment by the community for agricultural activities, illegal logging, and fires (Fig. 9.10).

Most of the villagers surrounding KSNP are involved in agricultural activities such as rubber and coffee production. Each household has 1-25 ha of land for agriculture; although illegal, some of this is done inside the KSNP area. Villagers enter the park because they need a large amount of land for agriculture. The productivity of coffee is very low, i.e., only 0.4 ton/ha or about one twentieth of normal yield (6-10 ton/ha). By increasing productivity of the crop just up to $4 \mathrm{t} /$ ha will reduce the demand for land by ten times from the usual one. At least there are four programs that can be implemented for improving communities' agriculture practices, namely, (1) improving seed quality as in the usual practices communities get seed from forest or from their garden, (2) improving maintenance and inputs as in the usual practices farmers do not use fertilizer and there are no regular weeding and spraying, (3) improving timing for harvesting to improve quality of coffee as in usual practices farmers tend to harvest the coffee before it gets mature, and (4) improving post-harvest management.

Enhancing capacity of farmers for improving agriculture practices could increase productivity and their income and thereby reduce the demand for land. This can be expected to reduce deforestation in KSNP. Strong assistance for the community will be essential to maintain KSNP.

The roadmap for the establishment of FMU may include at least the following aspects: (1) development of criteria and indicator for prioritizing forest area for FMU's establishment, (2) strategy on FMU institutional capacity building, (3) development of strategic work plan of the FMU, and (4) monitoring and evaluation system. The first aspect is very important to develop as level of risk and problems vary across regions. The availability of criteria and indicator will help the government in putting priority where FMU should be first established and 
ensure the presence of FMU will have significant impact on the improvement of performance in forest management or keep good forest management system to continue. The second aspect refers to steps of actions that would be implemented in developing capacity of the FMU organization. The third aspect refers to readiness of the FMU to carry out its role and function, and the fourth aspect refers to development of system to monitor and evaluate the performance of the FMU which will be needed for the development of improvement plan of the FMU. Kartodihardjo et al. (2011) proposed at least eight criteria for evaluating the FMU development performance, namely, (1) area stability, (2) forest use planning, (3) management plan, (4) organizational capacity, (5) inter-strata relations within government and regulations, (6) investment mechanism, (7) availability of access and community rights, and (8) forestry dispute settlement mechanism. In each typology indicators need to be developed for these criteria.

In terms of FMU organization capacity, capacity development should enable the FMU (1) to promote forestry professionalism and be able to perform management that can produce economic value from forest utilization that is balanced with the conservation, protection, and social functions of the forest; (2) to develop investments and provide work opportunities; (3) to prepare spatial-based planning and monitoring/evaluation; (4) to protect forest interests (including the public interest in the forest); (5) to respond to the range of local, national, and global forest management impacts (e.g., the forest's role in mitigating global climate change); and (6) to adjust to local conditions/typology as well as strategic environmental changes affecting forest management (Kartodihardjo et al. 2011).

\subsubsection{Incentive System for Certification}

As discussed above, the Government of Indonesia has issued a number of mandatory certification systems. These mandatory certification systems as mentioned previously are applied for all forest management/business entities (from large to small scale), namely, IUPHHK-HA, IUPHHK-HT, and IUPHHK-RE, and community forest management (CFM), namely, HTR and HKm (with permit utilization) and/or village forest/Adat forest (with management rights) and Hutan Rakyat (private forest, forest management on an owned land) as well as wood industries. For community-based forest management entities, obligation for doing certification may add burden as this will increase cost of production. On the other hand, some also argued the effectiveness of applying mandatory forest certification system, such as SFM/SVLK, in reducing illegal logging may also not be significant as the

\footnotetext{
${ }^{3}$ Community forest management (CFM) combines two things: a type of resource (forest) and a group of owner/manager (community). The term CFM broadly refers to various forms: Participatory Forest Management (PFM), Joint Forest Management (JFM), joint forest management (forest co-management), and Community-Based Forest Management (CBFM).
} 
certified company only able to manage the illegal activities within its company site, while market for illegal wood still exists.

Applying same rules for IUPHHK-RE (ecosystem restoration) as applied to other wood business forest activities in certification process may also be counterproductive. In the IUPHHK-RE, forest management units (concessionaires) are not allowed to do wood logging until forest reaches equilibrium conditions (may take time for about 35 years). Thus, in the short term, there will be noncash inflow to the concessionaires. While at present, treatments in term of fee and procedure for getting the permit (IUPHHK-RE) are similar to IUPHHK-HA (HPH) and IUPHHK-HT (timber plantation) as well as obligation for having certification. Without changing this policy, interest of private to do investment for production forest ecosystem restoration will be very low. Based on data from Purnama and Daryanto (2006), more than 10 million ha of production forest is suitable for IUPHHK-RE, while until now the total area of degraded production forests granted with IUPPHK-RE was only 185,005 ha.

Another mandatory certification system for agriculture plantation such ISPO which will oblige plantation companies to develop plasma farmer with minimum area of $20 \%$ of the total area of the plantation will also face dilemma. For new plantation, it may not be difficult to establish such plasma; however, for old plantation, this will be difficult as all their plantation areas are already planted. The only alternative ways is to find additional lands to be used for plasma. This will be very costly if no support mechanism from government.

Considering the above dilemma, incentive system for certification may need to be expanded. Some of potential incentive policies in supporting the mandatory certification system may include the following:

1. Expanding type of incentive for small business entity in getting certification. In the context of SVLK, program for increasing awareness of community on the importance of using certified wood product for saving environment should be progressively implemented. In reality, many wood consumers in developing nations do not care too much on this issue; the consumers are more interested in buying cheaper products. Based on discussion with stakeholder in East Java, price of illegal wood could be half of that the legal ones, so that wood products produced from these will be much cheaper. At present, the government has provided support for small holder company via government budget (APBN) to cover the cost for certification. This subsidy is still not enough as the cost for producing one unit product from certified timber is still higher than the one used illegal ones. In this regard, the incentive ${ }^{4}$ for small holder may need to increase so that the price of certified wood product can compete with the non-certified one. At the same time, the awareness-raising programs for community for consuming certified wood products have to be promoted. The subsidy can be

\footnotetext{
${ }^{4}$ Incentive could also be given in form of direct inputs subsidy.
} 
gradually reduced when domestic market for certified wood products increases. This type of policy could be also negotiated for debt-for-nature swap program.

2. Providing subsidy for business entities focusing on ecosystem restoration in having the mandatory certification.

3. Providing incentive for plantation companies in getting lands for plasma farmers as support for the company in meeting certification obligations. Implementation of this policy could be integrated with CFM programs.

\subsubsection{Incentive and Financial Policy for Accelerating the Establishment of Timber Plantation on Degraded Land and CFM for Sink Enhancement}

Many of degraded lands in forest area are claimed by community. When permit for using the land has been granted to an entity, conflict on the land normally emerges between the entity and the communities. For this reason, private entities prefer to use forested land in forest area for timber plantation or peatland as these areas normally have no or less conflict (no community claim on the land). Ideally, the government should issue permit on safe and conflict-free (clean and clear) forest areas. However, in most cases this is not the case, and the permit holders have to solve this land conflict problem. Level of conflict varies between regions, and social cost that has to be covered by the permit holder in the establishment of plantation will also vary. The high social costs prevent the permit holders to establish plantation. In this regard, the government needs to create incentive system for permit holders in handling this land conflict problem, and the types of the incentive may be varied depending on level of conflicts. The incentive could be in the form of reducing or exemption of administration/retribution fees for certain period of time depending on level of conflict. With this incentive policy, establishment of timber plantation in degraded land can be accelerated, and the dependency on natural forest for supplying wood will also reduce.

In managing the land conflict issue, the MoF also implements CFM program. The program gives access and right to communities to use the forest area or formalize/legalize the use of the land by the community. The communities have to apply for getting the permits (HTR, HKm, village, and Adat forests). However, the process for getting the permits is too complex for communities, and it is also a lengthy process. Without any assistance from their partners, communities are mostly unable to have the permits. Financial support from the government to communities in implementing the CFM is also available via BLU-P3H (General Services Agency). The amount of funding available for supporting the CFM is also huge, i.e., over a billion of USD. However, the absorption of fund is also very low, less than $1 \%$. Simplifying the process of getting permit and accessing fund from the BLU-P3H will also be crucial for accelerating the implementation of the CFM. As mentioned above, up to now the realization of the CFM program is far from target (see Table 9.4). 
Acceleration of the ecosystem restoration program which will have significant contribution to sink enhancement also needs incentive from the government. Incentive in the form of reducing administration/retribution fees for certain period or exemption from some of administration/retribution fees is recommended.

\subsubsection{Incentive and Financial Policies for Conserving Forest Carbon and Land Swap}

Implementation of land swap policies and exchange of forest functions in order to avoid deforestation (conserving carbon stock in forest) will need incentive and financial policy supports. Nurrochmat (2011) proposed a number of incentive and financial policy for supporting local government in implementing the policies. These include:

1. Financial policy on special allocation fund (Dana Alokasi Kusus, DAK) for conservation. This policy is an incentive from the national government to local government that commits to conserve forest for environmental services. Special allocation fund given to the conservation region should compensate the benefit loss coming from natural resource extraction or forest land conversion (conversion value). The Ministry of Finance plans to accommodate this in revision of Act No. 33/2004 (Ministry of Finance 2011).

2. Revision of fiscal balance law to enforcing "liability rule." The present fiscal balance law regulates the benefit sharing of natural resource extraction between national and local governments, as well as among local governments. The magnitude of sharing depends on the magnitude income that comes from the extraction of natural resources. In this case, the higher the number of the natural resources extracted by certain region, the bigger the benefit sharing received by the region. Revision of the existing fiscal balance law to be a more green fiscal balance is needed to avoid overexploitation and further destruction of natural resources in the regions due to short-term economic interest. A green fiscal balance shall give a proportional attention both in the reward side and in the punishment side to ensure the sustainability of nature resource management.

From the above discussion, it is quite clear that the issue of forest boundary (safe and conflict-free forest areas) and policy on the issuance of permit on the use forest area are two factors that will contribute to the achievement of SFM and REDD+ implementation. Development of boundaries between non-forest and forest areas needs acceleration. In regard with the forest boundary issues, Kemenhut (2011) reported that up to 2010 length of boundary between forest and non-forest areas and between forest functions reach $281,873 \mathrm{~km}$ covering area of about 14,238,516 Ha or about $10 \%$ of total forest area of Indonesia. This condition is considered as one of the important factors causing conflict of land right and access in all provinces. At present there is about 22.5-24.4 Mha of forest area in conflict, and a number of 
villages within forest area reach 19,420 villages (Dephut and BPS 2009 in Kartodihardjo et al. 2011).

The cost of developing forest boundary is quite expensive. Following the regulation from the $\mathrm{MoF}$, cost for changing forest functions that include developing forest boundary is 3.4 billion IDR per 12,000 ha. To reduce the cost, the process of the development of the forest boundary could be integrated with the development of FMU and conducted through participatory mapping process. In line with recommendation from Kartodihardjo et al. (2011), in addressing this boundary issue in connection with FMU establishment, there are several strategic directives that should be adopted depending on conditions in the FMU. These directives include:

1. Localization of all areas that have serious tenurial conflict into areas of noneffective production as a transitional policy and gradually building a collaboration to optimize achievement of sustainable forest management objectives.

2. Development of micro-spatial arrangements together with the community in order to reach mutual agreement with the community on the utilization norms for each spatial function.

3. Recommendation of legal settlement through the mechanism of revising the spatial arrangements in areas with serious tenurial conflict that is unlikely to be retained as forest areas.

4. Accommodation of community access to forest resources by rearranging the norms for utilizing such resources in accordance with sustainability principles.

5. Development of a mechanism for recognizing community management rights in areas of serious/minor tenurial conflict in the context of sustainable forest management. This mechanism serves as the basis for FMU managers to prepare licensing recommendations for communities.

6. Engagement of law enforcement for all issues relating to illegal activities.

Another important key factor for achieving SFM is availability and accessibility of funds for supporting SFM practices, particularly for engagement of communities in CFM. With the current system, the available fund to support CFM managed by the BLU-P3H as discussed above is not easily accessed by community due to the administration procedure. Policy allowing for transferring the funds to a financing system relatively easy to be accessed by community is required. Two types of financing systems that can be generated at regional level and may meet this need are "blending financing" and "hybrid micro-financing systems" (CER Indonesia and CCAP 2010). Blending financing system is a financing system that synergizes all financial sources such as CSR funding, government funding such as state budget (APBN), and local government budget (APBD) funds, banking, and international funding. This system can help leverage private funding and supports regional development by supporting community activities in urban agriculture and agroforestry including building human resource capacity through assistance and training activities.

Unlike the blending financing model, the hybrid micro-financing system will utilize more government funds than private funds. Funding to support CFM (HTR, $\mathrm{HKm}, \mathrm{HD} / \mathrm{HAd}$ ), which is currently managed by BLU-P3H, would be part of this 


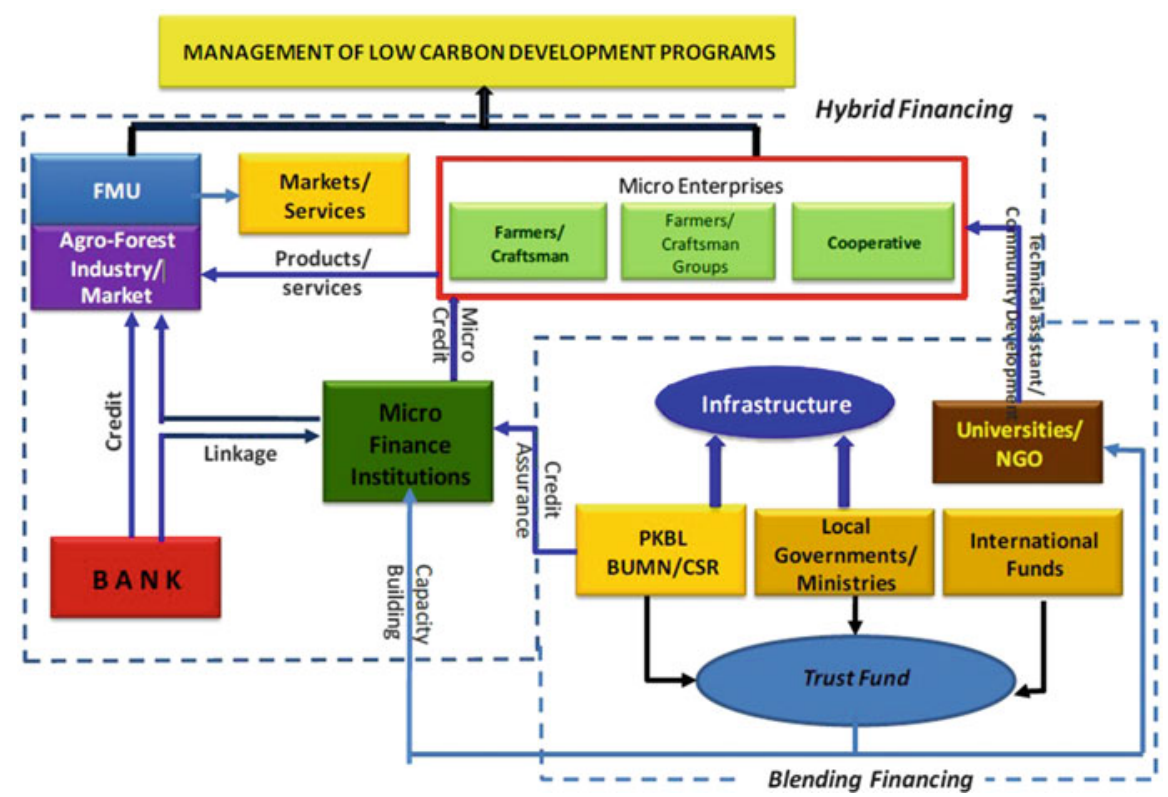

Fig. 9.11 Structure of financing systems to support low-carbon development (SFM and REDD+) (CER Indonesia and CCAP 2010)

financing system. In this system, government funds can be accessed by communities as capital fund assistance in the form of business credit. This system will require credit assurance institutions (LPKD - Local Credit Assurance Institution). The LPKD will provide government guarantees to banks so that if farmers are unable to pay on time, the LPKD will cover the credit and the farmers would pay later following rules as stated in Presidential Regulation No. 2/2008. This credit assurance institution has been developed in a few regions. The presence of this credit assurance institution is expected to support small- to medium-scale community business investments. Figure 9.11 presents the structure of the financing models and the connection with CSR and FMU. In the context of REDD+, both blending financing and hybrid micro-financing systems should provide positive incentives (low interest, tax deduction, concessional investment, etc.) for communities who propose activities that result in emission reductions from deforestation and degradation, conserving forest carbon, sustainable forest management practices, and sink enhancement.

Introduction of the incentive systems should not reduce the income of the government as the emission reduction which resulted from these policies will result in carbon payment. As decided by the Conference of the Parties (COP), payment from the implementation of REDD+ activities will be performance-based payment. This means that the party who decided to join the REDD+ scheme will be eligible to get the payment after the achievement in reducing the emission is measured, 
reported, and verified by the third independent parties. The magnitude of the emission reduction is measured against the reference emission level being used.

The study of Schmitz et al. (2014) indicated that by increasing investment in forest sector for facilitating change in technology (TC) at rate of $1 \%$ per year on top of the external investment, the forest destruction might decrease. The hypothesis of this scenario is that higher investments in TC can reduce the rate of forest destruction without any forest protection (e.g., investing in agricultural productivity reduces pressure on tropical forests without the necessity of direct protection; see section 9.6.5). Their study suggested that in the Pacific Asia (most of forest in Indonesia) without any significant change in forest protection program from Business as Usual (called as reference scenario), by 2050 the loss of forest cover might reach $43 \%$ of that of 2010 . If this figure is used for Indonesia, under the reference scenario, the remaining Indonesia forest cover by 2050 would be about 55.7 million ha or equivalent to total forest loss of about 43.4 million ha or about 1.08 million ha per year. This figure is slightly higher than the historical deforestation rate in the period 1990-2013, i.e., 0.822 million ha per year (see Sect. 9.3). With the increase of investment by $1 \%$ per year from the top of the external investment for the TC, it is expected that the forest loss in Indonesia would be only 13.5 million ha or equivalent to rate of deforestation of 0.337 million ha per year. As discussed above, the implementation of the above innovative financing and incentive policies might improve land and forest management, and this may further increase the potential of reducing emission from REDD+ activities.

Open Access This chapter is distributed under the terms of the Creative Commons Attribution Noncommercial License, which permits any noncommercial use, distribution, and reproduction in any medium, provided the original author(s) and source are credited.

\section{References}

Avisar R, Werth D (2005) Global hydroclimatological teleconnections resulting from tropical deforestation. J Hydrometeorol 6:134-145

Bahruni (2011) Conduct study and analysis on economic incentive framework of SFM as important option for forest based climate change mitigation-to reduce emission from and by tropical forest. ITTO Project Report RED-PD 007/09 Rev.2 (F)

Bappenas (2010) Naskah Akademis Rencana Aksi Nasional Penurunan Emisi Gas Rumah Kaca (GRK) 2010-2020. Badan Perencanaan Pembangunan Nasional, Republik Indonesia, Jakarta

Boer R (2009) Reduction emission from deforestation and forest degradation and sustainable development in Indonesia. In: Habito CF, Kojima S (eds) Mainstreaming sustainable development policies in East Asia. ERIA research project report 2008 No. 6-2. http://www.eria.org/ pdf/research/y2008/no6-2/Appendix3.pdf

Boer R (2012) Sustainable forest management, forest based carbon, carbon stock, $\mathrm{co}_{2}$ sequestration and green product in order to reduce emission from deforestation and forest degradation. Technical Report: Indonesia's Ministry of Forestry International Tropical Timber Organization RED-PD 007/09 Rev. 2 (F): Enhancing Forest Carbon Stock to Reduce Emissions from Deforestation and Degradation through Sustainable Forest Management (SFM) Initiatives in Indonesia, Jakarta 
Boer R, Nurrrochmat DR, Ardiansyah M, Purwawangsa H, Hariyadi, Ginting G (2012). Reducing agricultural expansion into forests in Central Kalimantan-Indonesia: analysis of implementation and financing gaps. Research report submitted to Prince of York. Bogor

Busch J, Ferretti-Gallon K, Engelmann J, Wright M, Austin KG, Stolle F, Turubanova S, Potapov PV, Margono B, Hansen MH, Baccini A (2015) Reductions in emissions from deforestation from Indonesia's moratorium on new oil palm, timber, and logging concessions. PNAS 112:1328-1333

CER Indonesia and CCAP (2010) Establishing integrated forest policies to reduce greenhouse gas emissions from deforestation and forest degradation at the District Level. Phase 1: the District of Musi Rawas, South Sumatra. Carbon Environmental Research Indonesia (CER Indonesia) and Centre for Clean Air Policy (CCAP), Bogor

CER Indonesia and CCAP (2011). Establishing Integrated Forest Policies to Reduce Greenhouse Gas Emissions from Deforestation and Forest Degradation at the District Level. Phase 2: The District of Musi Rawas, South Sumatra. Carbon Environmental Research Indonesia (CER Indonesia) and Centre for Clean Air Policy (CCAP), Bogor

Dale VH (1997) The relationship between land-use change and climate change. Ecol Appl 7:753-769

Dickinson R, Henderson-Sellers A (1988) Modelling tropical deforestation: a study of GCM landsurface parameterizations. Quart J R Meteor Soc 114:439-462

Directorate of Forest Resource Inventory and Monitoring (2015) Data dan Informasi Geospasial Dasar dan Tematik Kehutanan Terkini Tingkat Nasional. Presentation for Workshop on "Working Preparation for 2015", Auditorium Utama Manggala Wanabakti, 2 Maret 2015, Jakarta

Ditjen BUK (2011) Data Release Ditjen BUK Triwulan 1 Tahun 2011. Direktorat Jendral Bina Usaha Kehutanan, Jakarta. www.dephut.go.id

Hergoualc'h K, Verchot LV (2014) Greenhouse gas emission factors for land use and land-use change in Southeast Asian peatlands. Mitig Adapt Strateg Glob Change 19:789-807

Hosonuma N, Herold M, De Sy V, De Fries RS, Brockhaus M, Verchot L, Angelsen A, Romijn E (2012) An assessment of deforestation and forest degradation drivers in developing countries. Environ Res Lett 7 (12pp). doi:0.1088/1748-9326/7/4/044009

Houghton RA, House JI, Pongratz J, van der Werf GR, De- Fries RS, Hansen MC, Le Quéré C, Ramankutty N (2012) Carbon emissions from land use and land-cover change. Biogeosciences 9:5125-5142. doi:10.5194/bg-9-5125-2012

Kartodihardjo H, Nugroho B, Putro HR (2011) Forest Management Unit Development (FMU): concept, legislation and implementation. Directorate General of Forestry Planning, Ministry of Forestry, Jakarta

Kemenhut (2011) Rencana Kehutanan Tingkat Nasional (RKTN) tahun 2011-2030. Kementrian Kehutanan Republik Indonesia. Jakarta

Le Quere C, Andres RJ, Boden T, Conway T, Houghton RA, House JI, Marland G, Peters GP, van der Werf GR, Ahlstrom A, Andrew RM, Bopp L, Canadell JG, Ciais P, Doney SC, Enright C, Friedlingstein P, Huntingford C, Jain AK, Jourdain C, Kato E, Keeling RF, Klein Goldewijk K, Levis S, Levy P, Lomas M, Poulter B, Raupach MR, Schwinger J, Sitch S, Stocker BD, Viovy N, Zaehle S, Zeng N (2013) The global carbon budget 1959-2011. Earth Syst Sci Data 5:165-185. doi:10.5194/essd-5-165-2013

Ministry of Finance (2011) Policy brief: instrument and financing mechanism on reducing GHG emission. Fiscal Policy Agency, Ministry of Finance, Jakarta

MoE (2003) National strategy study on CDM in forestry sector. Ministry of Environment, Jakarta

MoE (2010) Indonesian second national communication to UNFCCC. Ministry of EnvironmentRepublic of Indonesia, Jakarta

MoFor (2014) Ministry of forestry statistics year 2013. Ministry of Forestry, Jakarta

Nugroho B, Sukardi D, Widyantoro B (2011) Study and analyze regulations concerning sustainable forest management, forest based carbon, carbon stock, $\mathrm{CO} 2$ sequestration and green product. ITTP Project Report RED-PD 007/09 Rev.2 (F) 
Nugroho B, Ridwan M, Hendri, Kartikasari K, Boer R (2014) Development of FMU as one of the strategies for ensuring the sustainability of emission reduction commitment. Technical report for LAMA-I Project, ICRAF, Bogor

Nurrochmat DR (2011) Review infrastructure framework and mechanism related to SFM as Important option in reducing emission from deforestation and forest degradation. Report submitted to Indonesia Ministry of Forestry and International Tropical Timber Organization, Jakarta

PT. Equality Indonesia (2007) Laporan akhir Pekerjaan Penilaian Tanaman GN-RHL/Gerhan tahun 2006/2007 Wilayah Propinsi Jabar. Bogor

Rusolono T, Tiryana T (2011) Review of existing sustainable forest management (SFM)-based projects in Indonesia. ITTO Project Report RED-PD 007/09 Rev.2 (F)

Schmitz C, Kreidenweis U, Lotze-Campen H, Popp A, Krause M, Dietrich JP, Muller C (2014) Agricultural trade and tropical deforestation: interactions and related policy options. Reg Environ Change, 16pp. doi:10.1007/s10113-014-0700-2

Shukla J, Nobre C, Sellers PJ (1990) Amazon deforestation and climate change. Science 247:1322-1325

Tim Pokja Kementrian Kehutanan (2010) Laporan Kelompok Kerja Kebijakan Kehutanan. Kementrian Kehutanan, Jakarta 